\title{
Papel de la biopsia de ganglio centinela en el manejo diagnóstico-terapéutico del melanoma de cabeza y cuello
}

\author{
The role of the sentinel node biopsy in the diagnosis and therapeutic \\ management of melanoma of the head and neck
}

\author{
A. García-Rozado González', C. Peña², V. Vieira², I. Uriarte³, J.L. López-Cedrún ${ }^{4}$
}

Resumen: Objetivo. La creciente incidencia del melanoma facial constituye un auténtico reto en muchas regiones del mundo, a pesar de medidas como la educación sanitaria de la población y realización de screenings poblacionales. Aunque también se emplean terapias no quirúrgicas, la mayoría de los melanomas se tratan en la actualidad mediante excisión quirúrgica. En los últimos años, la biopsia del ganglio centinela se ha incorporado como una técnica diagnóstica y terapéutica adicional, y ha permitido una reducción significativa de la morbilidad asociada al manejo quirúrgico del cuello. En el presente artículo pretendemos revisar la experiencia de nuestro equipo con el melanoma de cabeza y cuello en los últimos años, así como analizar retrospectivamente la incidencia de metástasis locoregionales, y la predictibilidad de la biopsia de ganglio centinela para su estadiaje. Diseño del estudio. Se ha revisado retrospectivamente nuestra experiencia en los dos últimos años con 12 casos de melanoma de cabeza y cuello en que se realizó linfoescintigrafía y biopsia de ganglio centinela. Resultados. La identificación del ganglio centinela mediante sonda de captación gamma se consiguió en 11 de los casos (91,6\%). Se identificaron un total de 21 ganglios centinela, es decir, 1,75 ganglios por paciente, siendo el nivel II cervical la localización más frecuente. Dos de ellos (9,52\%) resultaron afectados por melanoma. La morbilidad residual como consecuencia de la biopsia de los ganglios centinelas ha sido mínima. Conclusiones. A pesar del reducido tamaño de la muestra y de la falta de seguimiento a largo plazo, nuestros resultados son similares a los obtenidos por otros autores, lo que nos induce a considerar la linfoescintigrafía y biopsia de ganglio centinela como una técnica fiable, incluso ya desde fases iniciales de su implantación.

Palabras clave: Melanoma de Cabeza y Cuello; Ganglio Centinela; Linfoescintigrafía.

Recibido: 14.01.2005

Aceptado: 21.03.2005

\begin{abstract}
Objective. The ongoing incidence of malignant cutaneous melanoma of the head and neck has become a challenge in many regions of the world, in spite of prophylactic trials such as popular education and screening. Although non-surgical therapies are performed, most melanomas are actually treated by surgical excision. In the last few years, sentinel node biopsy has evolved as a diagnostic and therapeutic tool, and it has permitted a significant minimizing of the morbidity associated with the surgical management of the neck. This article is aimed at providing a thorough review of our experience in head and neck melanoma, as well as a retrospective analysis of locoregional metastases and the predictability of sentinel node biopsy for the staging of melanoma. Design. A retrospective review of our experience over the last two years has been carried out that includes 12 cases of head and neck melanoma where lymphoscintigraphy and sentinel node biopsy were performed. Results. Sentinel lymph nodes were identified using preoperative lymphoscintigraphy and intraoperative gamma probe in 11 cases (91.6\%). A total of 21 nodes were identified in the 12 patients, with an average number of 1.75 nodes per patient. The most frequent site where nodes were located was level II of the neck. Two nodes (9.52\%) were affected by melanoma. There was minimal morbidity related to this procedure. Conclusions. In spite of the reduced size of the sample and the short-term follow-up, our results are similar to those obtained by other authors, which leads us to believe that sentinel lymph node mapping with biopsy is a reliable technique for the diagnosis of regional spread in head and neck cutaneous melanoma, even in early development stages.
\end{abstract}

Key words: Head and Neck Melanoma; Sentinel Node; Lymphoscintigraphy.

\footnotetext{
1 Médico Adjunto. S. de Cirugía Maxilofacial. Complejo Hospitalario Juan Canalejo.

2 Médico Adjunto. S. de Dermatología. Complejo Hospitalario Juan Canalejo.

3 Médico Adjunto. S. de Medicina Nuclear. Centro Oncológico de Galicia.

4 Jefe de Servicio. S. de Cirugía Maxilofacial. C. H. Juan Canalejo. La Coruña. España.
}

\section{Correspondencia:}

Alvaro García-Rozado González

Rúa Perseo 15

15179 Oleiros, La Coruña, España

E-mail: agrozado@canalejo.org 


\section{Introducción}

De los casos nuevos de cáncer diagnosticados en países desarrollados, se estima que el melanoma cutáneo representa en la actualidad el $5 \%$ y $4 \%$ en hombres y mujeres, respectivamente. ${ }^{1}$ Estas cifras lo sitúan en el quinto y sexto cáncer más frecuente en varones y mujeres. Se calcula que sólo en EE.UU., en el año 2002 se diagnosticaron 53.600 nuevos casos de melanoma y 34.300 de melanoma in situ, y que 7.400 personas fallecieron víctimas de melanoma. Sin embargo, el aspecto más alarmante es que la incidencia de melanoma se incrementa aproximadamente un $5 \%$ cada año, y que esa creciente incidencia se asocia proporcionalmente a un incremento anual de la mortalidad en cifras absolutas. Al menos los porcentajes de supervivencia a los 5 años se han visto incrementados hasta un $89 \%$ en la actualidad, principalmente atribuible al incremento de la detección precoz de la enfermedad que permite un tratamiento más efectivo en estadios iniciales, más que a verdaderos avances terapéuticos.

El melanoma primario de cabeza y cuello representa entre el $25 \%$ y el $40 \%$ del total de melanomas, a pesar de que la región de cabeza y cuello ocupa tan solo un $9 \%$ del total de superficie corporal. ${ }^{2}$ Entre las razones que se atribuyen a tal desproporción se citan la exposición solar y la variación regional de la distribución de melanocitos cutáneos, de forma que el contenido de melanocitos en cabeza y cuello es 2 a 3 veces más alto que en el resto del organismo. ${ }^{3}$ Las localizaciones más frecuentes del melanoma de cabeza y cuello son la piel de la mejilla (46\%), cuello (20\%), scalp (18\%), pabellón auricular (12,5\%), nariz (2\%) y párpados (1\%). ${ }^{4}$ Clásicamente se considera que las áreas BANS (Back, Arm, Neck, Scalp) presentan peor pronóstico, y se ha demostrado que la piel del scalp presenta las peores cifras de supervivencia de cabeza y cuello, seguido de la región temporal, pabellón auricular, mejilla y cuello. ${ }^{5}$

Aunque los protocolos terapéuticos no se han modificado prácticamente en las últimas décadas y la excisión quirúrgica persiste como herramienta terapéutica fundamental en el manejo de los melanomas de cabeza y cuello, desde principios de la década de los 90 hemos asistido al desarrollo de la técnica de la biopsia de ganglio centinela, por primera vez descrita por Morton y cols., ${ }^{6}$ en 1992. Estos autores se basaron en los estudios de Wong y cols., ${ }^{7}$ quienes demostraron en un modelo de experimentación felino que una zona cutánea concreta drena siempre en un primer ganglio linfático, el ganglio centinela, y a partir de éste se disemina por el resto de los ganglios regionales.

Al igual que ocurre con otras enfermedades malignas de cabeza y cuello, la información que proporciona la biopsia de ganglio centinela mejora el estadiaje tumoral y tiene un gran interés pronóstico. En la actualidad se considera que la biopsia de ganglio centinela se ha incorporado plenamente al protocolo de manejo diagnóstico y terapéutico del melanoma de cabeza y cuello en casos N0. Prueba de ello es la publicación de numerosos artículos al respecto en la literatura médica. ${ }^{8-14}$ Asimismo, es una técnica mayoritariamente aceptada e integrada en el diagnóstico y tratamiento de otros cánceres, entre ellos el carcinoma epidermoide de cabeza y cuello o el carcinoma de células de Merkel, de interés en nuestra región anatómica. ${ }^{15-17}$ Incluso se realizan conferencias interna-

\section{Introduction}

Of the new cancer cases diagnosed in developed countries, cutaneous melanoma has been estimated in men and women at $5 \%$ and $4 \%$ respectively. ${ }^{1}$ These figures place it in fifth or sixth position of the most common cancers in men and women. It has been calculated that in the USA alone during the year 2002 some 53.600 new cases of melanoma were diagnosed together with 34.300 of in situ melanoma, and that there were 7.400 deaths from melanoma. However, the most alarming aspect is that the incidence of melanoma is increasing at a rate of approximately $5 \%$ each year, and that this growing incidence is linked with a proportional annual increase in mortality in absolute numbers. The five-year survival rate has at least increased and it currently stands at $89 \%$. This is chiefly due to an increase in the early detection of the disease that allows more effective treatment during the initial stages rather than to real therapeutic advances.

Primary melanoma of the head and neck represents 25\% to $40 \%$ of the total melanoma count, despite the fact that the head and neck represents just $9 \%$ of the whole body surface. ${ }^{2}$ Among the reasons attributed to this disproportion there is sun exposure and regional variation of cutaneous melanocyte distribution, to the extent that the number of melanocytes in the head and neck is two to three times higher than in the rest of the organism. ${ }^{3}$ The most common location of head and neck melanoma is the skin on the cheek (46\%), neck (20\%), scalp (18\%), outer ear (12.5\%), nose (2\%) and eye lids (1\%). ${ }_{4}^{4}$ The BANS areas (Back, Arm, Neck Scalp) have a worse prognosis traditionally, and it has been demonstrated that the skin of the scalp has the worst survival figures of the head and neck, followed by the area of the temples, outer ear, cheek and neck. ${ }^{5}$

Although the therapeutic protocols have practically not been modified over the last decades, and surgical excision continues to be the basic therapeutic tool for the management of melanoma of the head and neck, the early 90's witnessed the development of the sentinel node biopsy technique, first described by Morton et al. ${ }^{6}$ in 1992. These authors based their studies on Wong et al7 who demonstrated with an experimental feline model that each specific area of skin drained into a first lymph node, the sentinel node, and from here it drained to the rest of the regional nodes.

As occurs with other malignant diseases of the head and neck, the information provided by the sentinel node biopsy improves tumor staging and it is of great prognostic interest. It is currently felt that the sentinel node biopsy has been completely incorporated into the protocol for the diagnostic and therapeutic management of $\mathrm{NO}$ cases of head and neck melanoma. Proof of this is the publication of numerous articles on the subject in the medical literature. ${ }^{8-14}$ It is also a technique that has been accepted and integrated by the majority for the diagnosis and treatment of other cancers, including epidermoid carcinoma of the head and neck or 
Tabla 1. Muestra de pacientes afectos con melanoma de cabeza y cuello clínicamente N0 e intervenidos de biopsia de ganglio centinela en nuestro Servicio

\begin{tabular}{|c|c|c|c|c|c|c|c|c|c|c|c|}
\hline Paciente & Edad & Localización & $\begin{array}{c}\text { Tipo } \\
\text { melanoma }\end{array}$ & $\begin{array}{c}\text { Tamaño } \\
(\mathbf{m m})\end{array}$ & Clark & $\begin{array}{c}\text { Breslow } \\
(\mathrm{mm})\end{array}$ & $\begin{array}{l}\text { Retraso Dgto } \\
\text { - BGC (días) }\end{array}$ & $\begin{array}{lc}\text { to } & \text { Nivel } \\
\text { s) } & \text { ganglio }\end{array}$ & AP centinela & TNM & Estadio \\
\hline 1 & 68 & Mejilla izqda & MLM & 9 & IV & 5,2 & 27 & II - parótida & No identific. & T4a N0 & ॥ \\
\hline 2 & 81 & Mejilla dcha & MLM & 10 & IV & 3 & 76 & II - parótida & Negativo & T4a No & ॥ \\
\hline 3 & 44 & Mejilla dcha & MES & 8 & IV & 1,08 & 45 & ॥ & Negativo & T4a NO & ॥ \\
\hline 4 & 82 & Mejilla izqda & MLM & 16 & V & 7,3 & 92 & ॥ & Negativo & T4a N0 & ॥ \\
\hline 5 & 80 & Mejilla izqda & $\mathrm{MN}$ & 9 & V & 6 & 66 & II & Negativo & T4a N0 & ॥ \\
\hline 6 & 66 & Preauricular dcho & $\mathrm{MN}$ & 7 & IV & 4 & 36 & II & Positivo & T4a N2b & III B \\
\hline 7 & 59 & Labio superior & $\mathrm{MN}+\mathrm{MES}$ & 8 & 1 & 3,6 & 42 & II & Positivo & T4a N1a & III A \\
\hline 8 & 78 & Mejilla dcha & $\mathrm{MN}$ & 30 & IV & 10 & 24 & II & Negativo & T4a N0 & II \\
\hline 9 & 61 & Cervical dcho & $\mathrm{MN}$ & 8 & IV & 2,5 & 38 & V - II & Negativo & T4a N0 & II \\
\hline 10 & 40 & Scalp & $\mathrm{MN}$ & 8 & V & 8 & 20 & II dcho + II izqdo & Negativo & T4a NO & II \\
\hline 11 & 51 & Temporal izqdo & MES & 10 & II & 1,4 & 87 & $\mathrm{llb}$ & Negativo & T4a NO & II \\
\hline 12 & 49 & Temporal izqdo & MLM & 18 & II & 1,15 & 52 & Ilb + Preauricular & Negativo & T4a NO & II \\
\hline
\end{tabular}

Table 1. Sample of patients with clincally N0 melanoma of the head and neck that under went sentinel lymph node biopsy in our Service

$\begin{array}{ccccc}\text { Patient } & \text { Age } & \text { Localization } & \begin{array}{c}\text { Typo of } \\ \text { melanoma }\end{array} & \begin{array}{c}\text { Size } \\ (\mathbf{m m})\end{array} \\ 1 & 68 & \text { Left cheek } & \text { LMM } & 9 \\ 2 & 81 & \text { Right cheek } & \text { LMM } & 10 \\ 3 & 44 & \text { Right cheek } & \text { SSM } & 8 \\ 4 & 82 & \text { Left cheek } & \text { LMM } & 16 \\ 5 & 80 & \text { Left cheek } & \text { NM } & 9 \\ 6 & 66 & \text { Preauricular right } & \text { NM } & 7 \\ 7 & 59 & \text { Upper lip } & \text { NM + SSM } & 8 \\ 8 & 78 & \text { Right cheek } & \text { NM } & 30 \\ 9 & 61 & \text { Right neck } & \text { NM } & 8 \\ 10 & 40 & \text { Scalp } & \text { NM } & 8 \\ 11 & 51 & \text { Left temple } & \text { SSM } & 10 \\ 12 & 49 & \text { Left temple } & \text { LMN } & 18\end{array}$

$\begin{array}{ccc}\text { Clark } & \begin{array}{c}\text { Breslow } \\ (\mathbf{m m})\end{array} & \begin{array}{c}\text { Delay Diag } \\ - \text { SNB (days) }\end{array} \\ \text { IV } & 5.2 & 27 \\ \text { IV } & 3 & 76 \\ \text { IV } & 1.08 & 45 \\ \text { V } & 7.3 & 92 \\ \text { V } & 6 & 66 \\ \text { IV } & 4 & 36 \\ \text { I } & 3.6 & 42 \\ \text { IV } & 10 & 24 \\ \text { IV } & 2.5 & 38 \\ \text { V } & 8 & 20 \\ \text { II } & 1.4 & 87 \\ \text { II } & 1.15 & 52\end{array}$

Level of Node

II - parotid

II - parotid

II

II

II

$\mathrm{V}-\mathrm{II}$

II right + II left

Ilb

$\mathrm{Ilb}+$ Preauricular

$\begin{array}{ccc}\text { Sentinel AP } & \text { TNM } & \text { Stage } \\ \text { Not identified } & \text { T4a N0 } & \| \\ \text { Negative } & \text { T4a N0 } & \| \\ \text { Negative } & \text { T4a N0 } & \| \\ \text { Negative } & \text { T4a N0 } & \| \\ \text { Negative } & \text { T4a N0 } & \| \\ \text { Positive } & \text { T4a N2b } & \text { III B } \\ \text { Positive } & \text { T4a N1a } & \text { III A } \\ \text { Negative } & \text { T4a N0 } & \| \\ \text { Negative } & \text { T4a N0 } & \| \\ \text { Negative } & \text { T4a N0 } & \| \\ \text { Negative } & \text { T4a N0 } & \| \\ \text { Negative } & \text { T4a N0 } & \|\end{array}$

LMM: Lentigo Maligna Melanoma; SSM: Superficial Spreading Melanoma; NM: Nodular Melanoma

cionales encaminadas a la adopción de protocolos universales sobre las indicaciones y detalles de esta técnica. ${ }^{18}$

En el presente artículo se pretende describir nuestra experiencia con la biopsia de ganglio centinela en el melanoma de cabeza y cuello, así como definir las indicaciones para su realización y analizar la predictibiliad de la técnica.

\section{Material y método}

Se realiza un estudio retrospectivo sobre 12 pacientes afectos de melanoma de cabeza y cuello en estadio N0 en que se llevó a cabo biopsia de ganglio centinela. El primer caso se realizó en Julio de 2002 y el último de los incluidos en el estudio en Noviembre de 2004. La totalidad de los casos fueron remitidos a nuestro servicio por el Servicio de Dermatología, que previamente había realizado exéresis-biopsia de la lesión primaria. En la tabla 1 se resumen los datos principales correspondientes a la muestra de pacientes.
Merkel cell carcinoma, which are of interest in our anatomic region. ${ }^{15-17}$ International conferences are even held with the aim of adopting universal protocols with the indications for this procedure and its technical details. ${ }^{18}$

The purpose of the present article is to describe our experience with the sentinel node biopsy for head and neck melanoma, as well to define the indications for its use and to analyze the predictability of the technique.

\section{Material and Method}

A retrospective study was carried out of 12 patients with melanoma of the head and neck, with stage NO that underwent sentinel node biopsies. The first case was in July 2002 and the last one was in November 2004. All the cases had been referred to our Service by Dermatology Service that had previously carried out an excisional biopsy of the primary lesion. Table 1 shows the principal data corresponding to the patient series. 
Durante el periodo de tiempo 20022004 se han registrado un total de 176 melanomas en el servicio de Dermatología del Complejo Hospitalario Juan Canalejo de La Coruña. De ellos, 68 casos $(38,63 \%)$ se localizaban en el área de cabeza y cuello. Los 12 casos en que se realizó biopsia de ganglio centinela constituyen el $17,65 \%$ de los casos de melanoma en cabeza y cuello. Los criterios empleados para la indicación de la biopsia de ganglio centinela fueron los siguientes:

- Tumoración extirpable.

- Ausencia de adenopatías palpables (No).

- No evidencia de enfermedad metastásica.

- Melanomas con índice de Breslow de $1 \mathrm{~mm}$ o superior.

- Melanomas con índice de Breslow inferior a $1 \mathrm{~mm}$ que presentaban ulceración y/o nivel de Clark IV o superior.

- Se utilizó como criterio de exclusión los casos en que pudiera existir modificación del patrón de drenaje linfático por un procedimiento quirúrgico anterior o cualquier otra circunstancia. Tal situación no aconteció en ninguno de los casos evaluados en nuestro estudio.

La distribución por localizaciones anatómicas de cabeza y cuello de los casos incluídos en el estudio es la siguiente (Fig. 1): 6 melanomas en piel de mejilla, 2 en región temporal, 1 en cuero cabelludo, 1 en región preauricular, 1 en cuello, y 1 melanoma mucoso en labio superior. De los 12 pacientes biopsiados, 9 son mujeres (75\%) y 3 varones (25\%). La edad media de los pacientes en el momento de la biopsia de ganglio centinela fue de 63,25 años, con un rango de 40 a 82 años.

El tipo histológico de los melanomas incluídos en el estudio fue de melanoma nodular ( $\mathrm{MN}$ ) en 6 casos, melanoma sobre léntigo maligno (MLM) en 4 casos, y melanoma de extensión superficial (MES) en 2 casos (Fig. 2). Es de destacar que uno de los casos correspondiente a un melanoma mucoso de labio superior fue diagnosticado como melanoma nodular al realizarse la primera extirpación por el Servicio de Dermatología, y posteriormente diagnosticado como melanoma de extensión superficial cuando se realizó la ampliación de márgenes por nuestra parte. En 10 de los 12 casos (83,33\%) se realizó ampliación de los márgenes quirúrgicos de la lesión primaria al mismo tiempo que la biopsia de ganglio centinela.

La demora media desde el diagnóstico histológico por parte del Servicio de Dermatología hasta la realización de la biopsia de gan-
During the period 20022004, a total of 176 melanomas were registered by the Dermatology Service of the Juan Canalejo Hospital of La Coruña. Of these, 68 cases (38.64\%) were located in the area of the head and neck. The 12 cases that underwent sentinel node biopsies represent $17.65 \%$ of the melanoma cases of the head and neck. The criteria used to determine if a sentinel node biopsy was needed were the following:

- Removable tumor

- Absence of palpable swelling (NO).

- No evidence of metastasic disease.

- Melanomas of $1 \mathrm{~mm}$ or more on the Breslow scale.

- Melanomas of less than 1 $\mathrm{mm}$ on the Breslow scale that were ulcerated and/or Clark level IV or above.

- The exclusion criteria used related to cases where there could be a modification of the lymphatic drainage pattern due to a previous surgical procedure or any other circumstance. This situation did not arise in any of the cases evaluated in our study.

The distribution according to anatomic location in the head and neck of the cases included in out study was as follows (Fig. 1): 6 melanomas in the skin of the cheek, 2 in the region of the temples, 2 in the preauricular region, 1 in the neck, and 1 mucosal melanoma of the top lip. Of the 12 patients that had biopsies, 9 were female (75\%) and 3 were males (25\%). The mean age of the patients when the sentinel node biopsy was carried out was 63.25 years, with ages ranging between 40 and 82 .

The histological type of melanoma included in the study was of nodular melanoma (NM) in 6 cases, lentigo maligna melanoma (LMM) in 4 cases, superficial spreading melanoma (SSM) in 2 cases (Fig. 2). It should be pointed out that one of the cases of mucosal melanoma of the upper lip was diagnosed as nodular melanoma on excision by the Dermatology Service, and it was later diagnosed a superficial spreading melanoma when we widened the surgical margins. In 10 of the 12 cases (83.33\%) the surgical margins of the primary lesion were widened while the sentinel node biopsy took place. 
glio centinela por nuestra parte fue de 50,41 días, con un rango de 20 a 92 días.

Los niveles de Clark de los 12 casos de melanoma de cabeza y cuello en que se realizó biopsia de ganglio centinela se distribuyeron de la siguiente forma (Fig. 3): 6 casos de nivel IV, 3 de nivel $\mathrm{V}, 2$ casos de nivel II, y un melanoma mucoso. El índice de Breslow correspondiente presentó un rango de 1,08 $\mathrm{mm}$ a $10 \mathrm{~mm}$, con una media de 4,44 $\mathrm{mm}$. El tamaño de la lesión primaria, medido en el diámetro máximo de la pieza quirúrgica procedente de la exéresis-biopsia llevada a cabo por el Servicio de Dermatología, fue variable con un rango de 7 a $30 \mathrm{~mm}$, y un tamaño medio de $11,75 \mathrm{~mm}$. Ninguno de los pacientes incluidos en el estudio presentaba ulceración de la lesión primaria.

En todos los casos la detección de ganglios centinela se llevó a cabo mediante linfoescintigrafía para visualización del patrón de drenaje linfático, realizada el mismo día de la intervención quirúrgica. La linfoescintigrafía fue realizada en todos los casos por una misma facultativa especializada en Medicina Nuclear. Para el mapeo linfático se procedió a inyección intradérmica perilesional, en al menos 4 puntos alrededor de la lesión primaria, de un radiotrazador de sulfuro coloidal marcado con Tecnecio 99 (Tc99m), a razón de $3 \mathrm{mCi}$ en $0,3 \mathrm{ml}$ de suero, con partículas de $10 \mathrm{~nm}$. Aproximadamente al cabo de 10 minutos se tomaron imágenes gammagráficas estáticas (Fig. 4). A continuación se procedió a marcaje clínico de la zona cutánea correspondiente al ganglio con tinta indeleble (Fig. 5). Inmediatamente los pacientes fueron remitidos a quirófano para la biopsia de los ganglios marcados. Por lo tanto, la biopsia se realizó en todos los casos en el curso de las primeras 4 horas posteriores a la realización de la linfoescintigrafía.

En todos los casos la biopsia se realizó bajo anestesia general, y con anterioridad a la ampliación de los márgenes quirúrgicos de la lesión primaria, si ello estaba planificado. Como guía para la localización intraoperatoira del ganglio se utilizó una sonda de captación gamma (NeoProbe Neo2000TM Gamma Detection System,

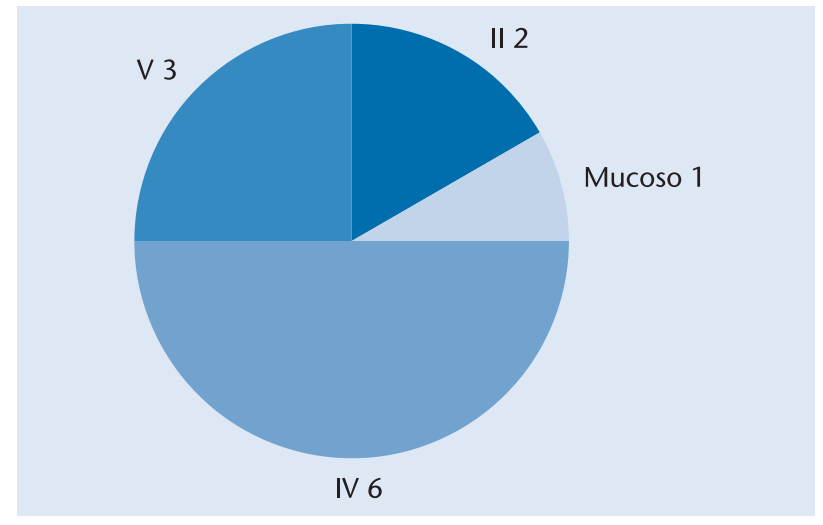

Figura 3. Distribución de niveles de Clark de melanomas incluídos en el estudio.

Figure 3. Distribution of the melanoma included in the study according to Clark's levels.

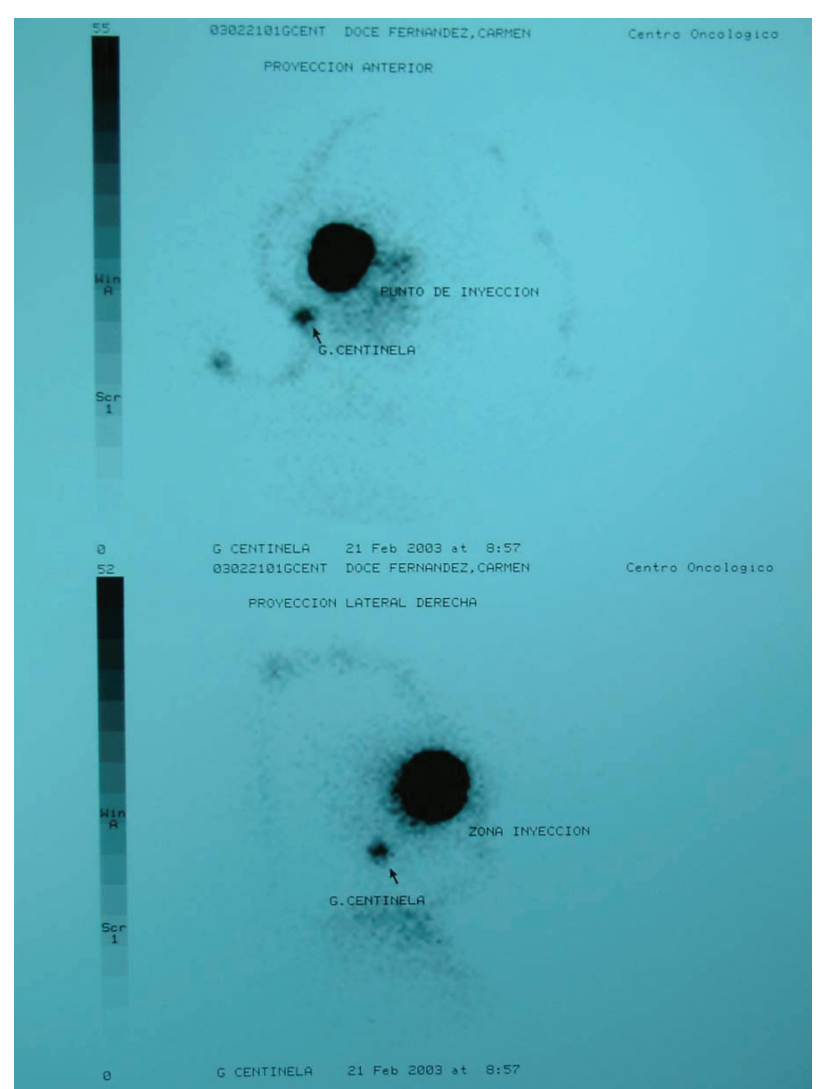

Figura 4. Imagen gammagráfica obtenida tras la inyección de sulfuro coloidal con Tc99m.

Figure 4. Gammagraphic image obtained following Tc99 sulfur colloid injection.
The average delay between the histological diagnosis by the Dermatology Service to our carrying out the sentinel node biopsy was 50.41 days, with the number of days ranging between 20 and 92 . The Clark levels in the 12 cases of the head and neck melanoma where the biopsy of the sentinel node was carried out were as follows (Fig. 3): 6 cases of Level IV, 3 cases of Level V, 2 cases of Level II, and 1 mucosal melanoma. The corresponding Breslow scale ranged between 1.08 $\mathrm{mm}$ and $10 \mathrm{~mm}$, with an average of $4.44 \mathrm{~mm}$. The size of the primary lesion, taking the maximum diameter of the surgical specimen from the excisional biopsy carried out by the Dermatology Service was variable, ranging between 7 and $30 \mathrm{~mm}$, with a mean size of $11.75 \mathrm{~mm}$. None of the patients included in the study had ulceration of the primary lesion.

All the sentinel node detection was done with lymphoscintigraphy in order to visualize the lymphatic drainage pattern, and it was carried out on the same day of the surgical intervention. The lymphoscintigraphy was carried out in all cases by the same doctor specialized in Nuclear Medicine. For the lymphatic mapping, perilesional intradermic injections were used in at least 4 points around the primary lesion with technetium (tc 99m) radiotracer sulfur colloid with a dose of $3 \mathrm{mCi}$ in $0.3 \mathrm{ml}$ of serum with a particle size of $10 \mathrm{~nm}$. After approximately 10 minutes static gammagraphic images were taken (Fig. 4). Next, the cutaneous area that corresponded to the node was marked clinically with indelible ink (Fig. 5).

The patients were then sent immediately to the operating room for the biopsy of the nodes that had been marked. 
Neoprobe Corporation, Dublin, Ohio) (Fig. 6). Como peculiaridad de la técnica, no se empleó colorante azul para identificar el ganglio, basándonos en nuestra experiencia con tatuajes residuales en otras lesiones malignas de cabeza y cuello.

La disección quirúrgica del ganglio se realizó de forma convencional, de acuerdo a los standards de disección cervical universalmente aceptados. Un ganglio fue considerado como centinela si el contaje radiactivo estaba en concordancia con los hallazgos linfoescintigráficos. Asimismo, se consideró como ganglio centinela cualquier otro ganglio con elevado contaje radiactivo (100 o 1000 veces mayor, según el programa de sensibilidad de la sonda) y/o localizado tan próximo al lugar de inyección del radiotrazador o a otro ganglio radiactivo que no pudiera ser individualizado en la linfoescintigrafía.

El contaje radiactivo con la sonda se realizó del ganglio in-vivo y ex-vivo (Fig. 7). Protocolariamente se comprobó la existencia de captación residual en el lecho del ganglio. Se realizó la ampliación de márgenes de la lesión primaria en los casos planificados, en función de radicalidad de la cirugía previa, el tamaño de la lesión y la profundidad de invasión del melanoma (índice de Breslow).

La evaluación histopatológica de los

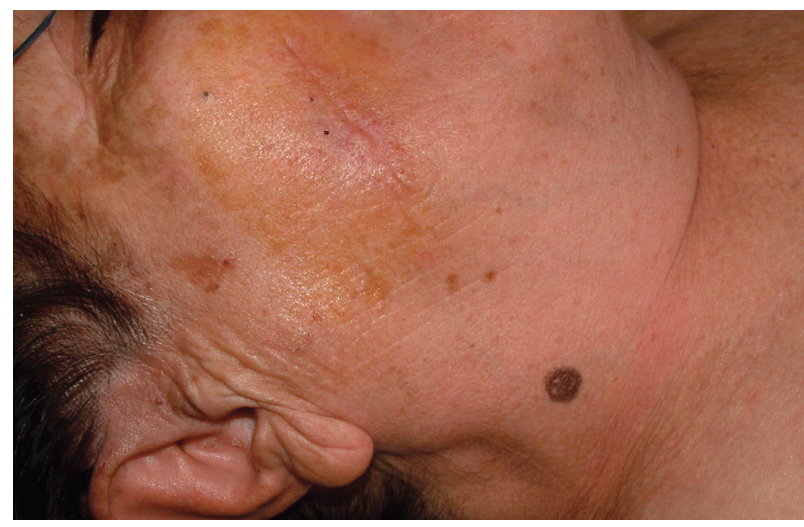

Figura 5. Marcaje con tinta de la zona del ganglio para ayudar a su identificación intraoperatoira.

Figure 5. Ink marking of the nodal area to aid intraoperative identification.

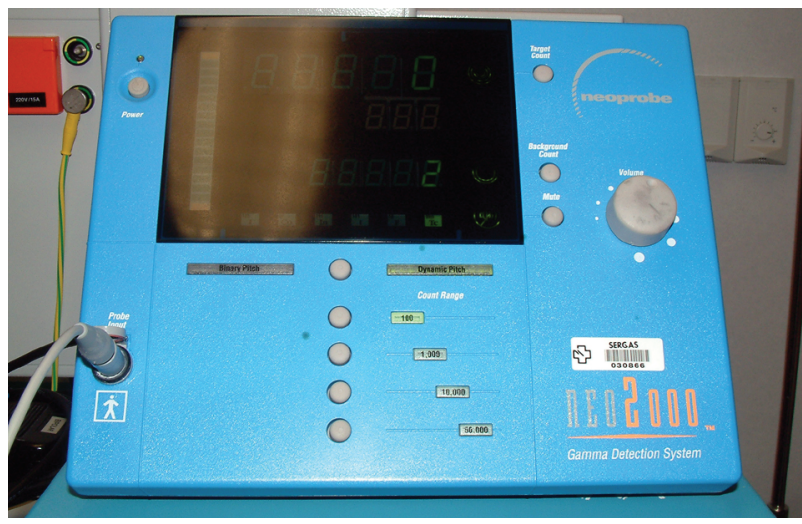

Figura 6. Sonda de captación utilizada para la identificación intraoperatoria del ganglio centinela.

Figure 6. Probe used to identify the sentinel node intraoperatively.
The biopsy was carried out in all cases during the first 4 hours that followed the lymphoscintigraphy.

The biopsy was carried out in all cases under general anesthesia and before amplifying the surgical margins of the primary lesion, if this was planned. In order to locate the node intraoperatively a gamma detector (NeoProbe Neo2000 ${ }^{\text {TM }}$ Gamma Detection System, Neoprobe Corporation, Dublin, Ohio) was used (Fig. 6). A characteristic of our technique was that blue dye was not used to identify the node, given our experience with residual tattoos in other malignant lesions in the head and neck. The surgical dissection of the node was carried out in the conventional way, according to the universally accepted standards for neck dissection. A node was considered a sentinel node if the radioactive count agreed with the lymphoscintigraphic findings. Thus, any other node with a high radioactive count (100 or 1000 times greater, according to the ganglios centinela se realizó de forma minuciosa en al menos 6 secciones, o hasta 12 si el ganglio era mayor de $1 \mathrm{~cm}$. Se realizó estudio histológico convencional con tinción con Hematoxilina-Eosina y estudio inmunohistoquímico con S-100, HMB45, y/o Melan A.

Ningún caso se perdió en seguimiento clínico, excepto un paciente que fue éxitus. El tiempo medio de seguimiento desde la fecha de la biopsia de ganglio centinela fue 14,33 meses (rango 2-30 meses).

\section{Resultados}

Se ha identificado ganglio centinela en 11 de los 12 casos estudiados $(91,6 \%)$. El caso en que no se identificó ganglio correspondía a un melanoma de piel de mejilla, y se objetivó un elevado contaje radiactivo en el parénquima de la cola de parótida ipsilateral. Se procedió a resección del tejido con elevada captación radiactiva y se comprobó la reducción casi total de contaje con sonda en el lecho quirúrgico. El estudio histopatológico posterior reveló la presencia de tejido glandular y ausencia de ganglios linfáticos. sensitivity program of the probe) was considered a sentinel node and/or that was located so close to the injection site of the radio-tracer to another radioactive node that it could not be singled out in the lymphoscintigraphy.

The radioactive count was carried out in vivo and ex vivo using the probe (Fig. 7). Following the established protocol, the existence of residual counts in the nodal bed was checked. Amplification of the margins was carried out when planned, depending on how radical the previous surgery had been, the size of the lesion and how deep the melanoma invasion was (Breslow scale).

The histopathological evaluation of the sentinel nodes was carried out very thoroughly with at least six sections, or up to 12 if the node was larger than $1 \mathrm{~cm}$. A conventional histologic study was carried out with hematoxylin-eosin stain and immunohistochemistry study for S-100, HMB45, and/or Melan-A.

During the clinical follow-up no case was lost, with the exception of one exitus case. The average follow-up time (with a range of 2-30 months). from the date the sentinel node biopsy was 14.33 months 
En 5 casos $(41,66 \%)$ se encontró más de un ganglio radiactivo, considerándose también como ganglios centinela. En un caso de melanoma de línea media de cuero cabelludo, se objetivaron cuatro ganglios centinela, dos en cada lado, en nivel II cervical bilateral. En total se identificaron 21 ganglios centinela, es decir, 1,75 ganglios por paciente.

La localización de los ganglios centinela identificados se distribuye de la siguiente manera (Fig. 8): 17 ganglios en nivel II cervical, 1 en nivel I, 1 en nivel $\checkmark$, y 2 ganglios intraparotídeos.

Dos de los casos $(16,66 \%)$ presentaron un ganglio centinela afectado por melanoma, lo que representa el 9,52\% del total de 21 ganglios estudiados. Estos dos ganglios positivos se encontraron localizados en nivel II, y correspondieron a un caso de melanoma preauricular y a otro caso de melanoma de mucosa labial. En ambos casos se procedió al vaciamiento ganglionar cervical radical, y al tratamiento adyuvante con radioterapia e interferon alfa- $2 b$ en altas dosis. El primero de los casos con melanoma preauricular presentó diseminación sistémica con metástasis hepáticas y pulmonares, resultando éxitus al cabo de 12 meses de la realización del vaciamiento cervical. En el segundo caso con positividad de ganglio centinela, melanoma mucoso de labio superior, también se realizó tratamiento adyuvante con radioterapia e interferon alfa-2b en alta dosis, estando el paciente por el momento vivo $y$ libre de enfermedad tras 13 meses de seguimiento.

Los 10 casos restantes cuyos ganglios centinela resultaron histológicamente indemnes están siendo sometidos a controles periódicos ambulatorios. Uno de los casos, correspondiente a un melanoma de mejilla, presentó al cabo de 17 meses un ganglio linfático intraparotídeo afectado por melanoma, diagnosticado por TC y por citología. Durante ese tiempo la paciente ha sido controlada clínica y radiológicamente de forma periódica, con estudio TC en que no se objetivó lesión metastásica locoregional. Ello, unido al tiempo trascurrido hasta la aparición de la metástasis linfática, nos ha llevado a no considerar el caso como un falso negativo de la técnica. La paciente ha sido sometida a parotidectomía total con sacrificio de las ramas inferiores del nervio facial, y vaciamiento cervical radical.

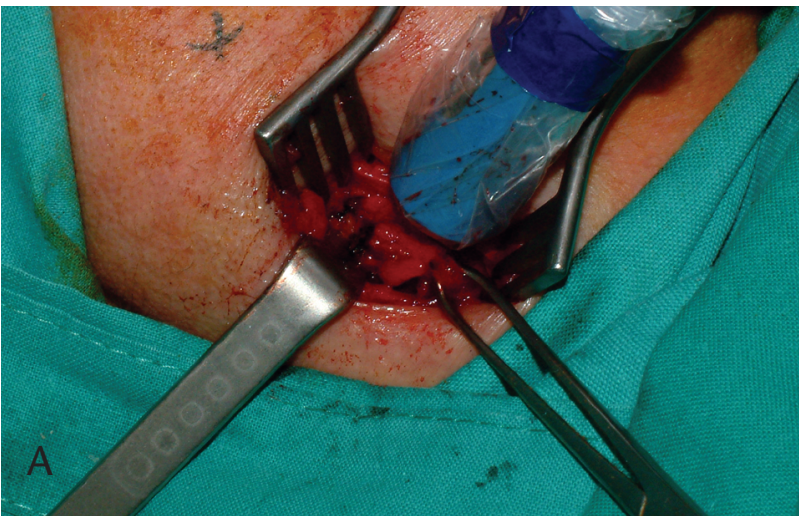

Results

Of the 12 cases studied, a sentinel node was identified in 11 cases (91.6\%). The one case where a sentinel node was not identified corresponded to melanoma of the skin of the cheek, and a high radioactive count was noted in the parenchyma of the ipsilateral parotid tail. The tissue with the high radioactive activity was resected and a near total reduction of the count was verified using a probe on the surgical bed. The posterior histopathologic study revealed the presence of glandular tissue and the absence of lymph nodes.

In 5 cases (41.66\%) a radioactive node was found that was considered the sentinel node. In one case of scalp melanoma of the midline, four sentinel nodes were observed, two in each side, bilateral neck level II. A total of 21 sentinel nodes were identified, that is 1.75 nodes per patient.

The location of the identified sentinel nodes was as follows (Fig. 8): 17 nodes in Level II neck, one in Level I, one in Level $V$ and 2 intraparotid nodes.

Two cases (16.66\%) had sentinel nodes affected by melanoma, which represents 9.52\% of all the 21 lymph nodes studied. These two positive glands were found in Level II, and they corresponded to one case of preauricular melanoma and to another case of melanoma of the lip mucosa. In both cases radical node dissection of the neck was carried out, and adjuvant therapy was give with high-dose interferon alfa- $2 b$. The first case with preauricular melanoma had systemic dissemination with liver and lung metastasis, resulting in exitus 12 months after the radical neck dissection. The second positive sentinel lymph node was related to a case of mucosal melanoma of the top lip. Adjuvant treatment was carried out with radiotherapy and high-dose interferon alfa- $2 b$. The 
La morbilidad residual obtenida con las biopsias de ganglio centinela realizadas se reduce a la cicatriz quirúrgica y la violación de los espacios faciales cervicales. No hemos objetivado ninguna secuela en estructuras nobles, ni concretamente en ramas del nervio facial.

\section{Discusión}

El melanoma es una enfermedad maligna de curso impredecible, particularmente en la región de cabeza y cuello. Sin embargo, es un hecho conocido que la diseminación linfática con frecuencia precede a la diseminación sistémica. ${ }^{19,20}$ De hecho, la afectación linfática está presente hasta en un $30 \%$ de pacientes sin ganglios clínicamente palpables. ${ }^{14} \mathrm{El}$ riesgo de metástasis ganglionares ocultas se incrementa a medida que el espesor del tumor primario aumenta. ${ }^{11}$ Lesiones menores de $1 \mathrm{~mm}$ de espesor presentan un riesgo de metástasis ocultas de menos de un $5 \%$, mientras que en lesiones de espesor mayor de $1 \mathrm{~mm}$ este riesgo asociado se incrementa a un 30 a $50 \% .{ }^{11}$

Un ganglio centinela es el primer escalón ganglionar, en teoría el ganglio linfático que recibe directamente el drenaje de la localización primaria del tumor. Sería por tanto el primer ganglio afectado en caso de diseminación linfática de la tumoración. En esta hipótesis se basan los conceptos de la biopsia de ganglio centinela. ${ }^{6}$

Desde las primeras publicaciones, la biopsia de ganglio centinela ha demostrado utilidad en diferentes aspectos del manejo del melanoma, entre los que se incluyen el diagnóstico de extensión, el estadiaje, el pronóstico y el tratamiento. ${ }^{21}$ En la actualidad está aceptado que la afectación ganglionar constituye el factor independiente con mayor significación pronóstica en pacientes con melanoma, incluso superior al índice de invasión de Breslow y a la ulceración de la lesión primaria. ${ }^{22,23}$ De hecho, el estado del ganglio centinela se incluye como factor pronóstico en el nuevo sistema de estadiaje de la AJCC del 2002. ${ }^{24}$

Desde el punto de vista diagnóstico, parece demostrado que es la técnica menos agresiva y más efectiva para demostrar la presencia de metástasis ganglionares ocultas, ${ }^{25}$ con una sensibilidad significativamente mayor que técnicas de imagen sofisticadas como TC, RM y PET. ${ }^{26}$ Además, la detección precoz de micrometástasis permite realizar inmediatamente vaciamientos ganglionares de rescate, e identifica pacientes de melanoma susceptibles de recibir tratamiento adyuvante con interferon alfa- $2 \mathrm{~b} .{ }^{27}$

Pu y cols., ${ }^{28}$ encontraron que el $91,3 \%$ de los pacientes con ganglio centinela positivo no presentaban otras adenopatías afectas en el estudio histológico de la linfadenectomía radical. El restante 8,7\% de los casos presentó un ganglio adicional afecto. Esta baja prevalencia de ganglios linfáticos adicionales positivos en linfadenectomías completas sugiere que, cuando existen micrometástasis en los ganglios linfáticos regionales, en la mayoría de los casos de estadios precoces de melanoma de cabeza y cuello están confinadas en los ganglios centinela.

La linfoescintigrafía y biopsia de ganglio centinela ha sustituido al vaciamiento ganglionar electivo en estadios precoces de melanoma de cabeza y cuello, reduciendo con ello la morbilidad asociada a su manejo quirúrgico. Presenta una clara ventaja sobre la patient is currently alive and disease-free after a 13-month follow-up.

The remaining 10 cases with histologically unharmed sentinel nodes are under periodic control on an outpatient basis. One of these cases corresponded to melanoma of the cheek, and melanoma of the intraparotid lymph nodes, which was diagnosed by CAT scan and by cytology, appeared 17 months later. During this time the patient was periodically controlled clinically and radiologically by CAT scan and no locoregional metastatic lesion was observed. This, added to the time elapsed before the appearance of lymphatic metastasis led us to believe that the case was not a false negative of the technique. The patient underwent a total parotidectomy. The lower branches of the facial nerve were sacrificed and radical neck dissection was carried out.

The residual morbidity as a result of the sentinel node biopsies was just the surgical scar and the violation of the facial spaces in the neck. No sequelae in important structures were observed nor in any specific branches of the facial nerve.

\section{Discussion}

Melanoma is a malignant disease with an unpredictable clinical course, particularly in the area of the head and neck. It is well-known, however, that lymphatic dissemination often precedes systemic dissemination. ${ }^{19,20}$ In fact, in $30 \%$ of patients the lymph nodes are affected even though this is not clinically palpable. ${ }^{14}$ The risk of occult nodal metastasis increases the thicker the primary tumor. ${ }^{11}$ Lesions with a thickness that is under $1 \mathrm{~mm}$ have a risk of metastases of less than 5\% while associated risk increases by 30 to $50 \%$ when the lesions is thicker than $1 \mathrm{~mm} .{ }^{11}$

The sentinel node is the first nodal echelon that in theory directly receives drainage from the primary tumor site. It would therefore be the first node affected if there was lymphatic dissemination of tumor cells. The concepts behind the sentinel node biopsy are based on this hypothesis. ${ }^{6}$

Even from the first publications, the sentinel node biopsy has proved very useful in various aspect of melanoma management, including diagnosis for regional extension, staging, prognosis and treatment ${ }^{21}$ It is currently accepted that nodal involvement represents an independent factor with the greatest prognostic value for patients with melanoma, that is even more significant than the invasion depth according to Breslow's scale and to the primary lesion being ulcerated.22,23 In fact, in the AJCC of 2002 sentinel node status is included as a prognosis factor. ${ }^{24}$

From the point of view of diagnosis, it appears to be the least aggressive technique and the most effective for revealing the presence of occult nodal metastasis. ${ }^{25}$ It has a sensitivity that is significantly greater than that of sophisticated imaging techniques such as the CAT scan, MR and PET. ${ }^{26}$ In addition, early detection of micrometastasis permits imme- 
linfadenectomía electiva al permitir identificar ganglios de forma individualizada que pueden ser resecados y examinados con mayor minuciosidad y con bajo coste. ${ }^{29}$ Aunque todavía existe controversia sobre si la biopsia de ganglio centinela modifica el pronóstico del paciente, se ha impuesto mayoritariamente como un potente indicador del pronóstico de la enfermedad. ${ }^{8}$

En el melanoma diagnosticado en población pediátrica parece que la utilidad de la biopsia del ganglio centinela es tan alta como en adultos. ${ }^{30}$

Con todo ello, las indicaciones aceptadas por la mayoría de autores para la realización de biopsia de ganglio centinela serían aquellos melanomas en los que no exista evidencia de metástasis ganglionares o a distancia, con un Breslow de $1 \mathrm{~mm}$ o superior, ${ }^{31} \mathrm{y}$ en melanomas con índice de Breslow menor de $1 \mathrm{~mm}$ que presenten ulceración de la lesión primaria y/o nivel IV de Clark o superior. ${ }^{3,24}$ Otros autores defienden la indicación en melanomas de más de $4 \mathrm{~mm}$ con la finalidad de aportar información sobre el pronóstico de la enfermedad, a pesar de que estos melanomas presentan un alto riesgo de desarrollar metástasis a distancia. ${ }^{32}$

Uno de los problemas que se plantean en el manejo terapéutico del melanoma de cabeza y cuello se refiere a la impredictibilidad del patrón de drenaje linfático de cabeza y cuello. Según algunas publicaciones, en un 34 a $84 \%$ de los pacientes, el drenaje linfático es discordante con la predicción clínica, ${ }^{33,34}$ y en aproximadamente un $10 \%$ de casos se objetiva un drenaje bilateral. ${ }^{21} \mathrm{El}$ área de mayor discordancia corresponde a los ganglios linfáticos retroauriculares. ${ }^{34}$ Por el contrario, otras publicaciones concluyen que esta discrepancia entre la predicción clínica y la realidad patológica acontece en tan solo un 7,7\% de los casos, y que la predictibilidad del patrón linfático en melanoma de cabeza y cuello es de 92,3\%.29 La linfoescintigrafía aportaría información adecuada sobre la anatomía linfática para prevenir que se escaparan estas metástasis de patrón impredecible.

Sin embargo, el mapeo linfático en cabeza y cuello presenta algunos problemas particulares. Resulta más difícil de visualizar el drenaje linfático mediante linfoescintigrafía que en otras áreas del organismo debido a que los potenciales ganglios centinela se encuentran a menudo en las proximidades del área de inyección del radiotrazador, y además con riesgo de falsear la captación intraoperatoria por la sonda gamma. ${ }^{14}$ Algunos autores propugnan utilizar un sulfuro coloidal de menor actividad en cabeza y cuello. ${ }^{35}$ Además, el trazador suele viajar muy rápido, por lo que en 10 min se obtienen imágenes de captación ganglionar, sin necesidad de requerir linfoescintigrafías dinámicas. Sin embargo, sí resulta visible más de un ganglio, es difícil distinguir si corresponden a ganglios centinela o no-centinelas. Según algunos autores, este problema podría resolverse con el uso de trazadores isotópicos con partículas de mayor tamaño, que se acumularían de forma predominante en el primer escalón ganglionar y tendrían menor capacidad de viajar a escalones ganglionares más distales. ${ }^{14}$

El número de ganglios por paciente que hemos encontrado en nuestro estudio es de 1,75 ganglios. En las series revisadas el rango va de 1,25 a 2,8 ganglios por paciente. ${ }^{10-12}$

Otra controversia que suscita la biopsia de ganglio centinela en melanoma de cabeza y cuello viene determinada por la morbilidad diately carrying out more extensive salvage resection together with the identification of patients with melanoma that require adjuvant treatment with interferon alfa- $2 b .{ }^{27}$

Pu et a ${ }^{28}$ found that $91.3 \%$ of patients with positive sentinel nodes did not have additional positive lymph nodes in the histological study following radical lymphadenectomy. The remaining $8.7 \%$ of the cases had one additional positive lymph node. This low prevalence of additional positive lymph nodes in complete lymphadenectomies suggests that when there is micrometastasis in regional lymph nodes, in most early stage head and neck melanoma, this is limited to the sentinel node.

Lymphoscintigraphy and sentinel node biopsies have substituted elective node dissection in early-stage melanoma of the head and neck, thus reducing the morbidity associated with surgical treatment. It has a clear advantage over elective lymphadenectomies as the lymph nodes that can be resected can be individually identified, more closely examined and at a much lower cost. ${ }^{29}$ Although there is still controversy as to whether the sentinel node biopsy modifies patient prognosis, it has been imposed largely as a strong indicator of disease prognosis. ${ }^{8}$

The utility of the sentinel node biopsy in the pediatric population appears to be as beneficial as it is in adults. ${ }^{30}$

In view these finding, the indications accepted by most authors for carrying out sentinel node biopsies include melanoma with no evidence of nodal or distant metastasis and with a Breslow thickness of $1 \mathrm{~mm}$ or over, ${ }^{31}$ and melanoma with a thickness under $1 \mathrm{~mm}$ if the primary lesion is ulcerated and/or with Clark level IV or above.3, 24 Other authors defend the indication for melanomas of $4 \mathrm{~mm}$ or above if the aim is to provide information on the prognosis of the disease, in spite of the fact that these melanomas carry a high risk of distant metastasis. ${ }^{32}$

One of the problems posed in the therapeutic management of melanoma of the head and neck refers to the unpredictable pattern of lymphatic drainage in the head and neck. According to some publications, in 34 to $84 \%$ of patients, lymphatic drainage is discordant with clinical predictions 33 , 34 and in approximately $10 \%$ of cases bilateral drainage is observed. ${ }^{21}$ The area that is most discordant corresponds to the retroauricular lymph nodes. ${ }^{34}$ Other publications on the other hand, conclude that this discrepancy between clinical prediction and pathologic reality appears in only $7.7 \%$ of cases, and the predictability of the lymphatic pattern of head and neck melanoma is $92.3 \% .^{29}$ The lymphoscintigraphy provides adequate information on the lymphatic anatomy to prevent these metastases with unpredictable patterns from going undetected.

However, lymphatic mapping of the head and neck has some of its own particular problems. Visualizing lymphatic drainage by means of lymphoscintigraphy is more difficult than in other areas of the organism, as potential sentinel nodes are often found overlapping the injection area of the radiotracer, and there is the additional risk of a false intra- 
asociada. Un elevado número de estos ganglios son pequeños y se encuentran localizados en áreas que no son fácilmente accesibles, por ejemplo en el parénquima de la glándula parótida, con el consiguiente riesgo de producir lesiones en estructuras nobles. En nuestro estudio no hemos encontrado ninguna secuela de este tipo. Tampoco hemos encontrado morbilidad residual remarcable en los diferentes trabajos publicados en la literatura médica. ${ }^{10-13,27}$

En la literatura existen referencias a la capacidad de absorción del sulfuro coloidal de Tc-99m por los tejidos glandulares. ${ }^{35}$ Esto incrementa el nivel de radiación en la red linfática y provoca dificultades intraoperatorias con el contaje de la sonda en áreas próximas a estructuras glandulares, situación que acontece con frecuencia en casos de melanoma facial. En nuestro estudio, el caso que no se identificó ganglio centinela presentó elevado contaje en la región de la cola parotídea, y se procedió a resecar dicho tejido con alta radiactividad, aunque en el estudio histológico posterior no se objetivó tejido ganglionar.

El empleo de algún tipo de colorante azul también suscita controversia. Algunos autores,12,36 defienden la utilización de azul de metileno y consideran que localizan mejor los ganglios intraoperatoriamente, aunque también refieren que el colorante azul se visualiza en menos ocasiones en cabeza y cuello que en otras regiones anatómicas. En nuestra experiencia hemos encontrado secuelas de tinciones permanentes por colorante azul en casos utilizados para biopsia de ganglio centinela en carcinoma epidermoide intaoral. Ello nos ha llevado a evitar su empleo intraoperatorio sistemático, máxime cuando en el caso del melanoma la inyección del colorante se realiza en áreas faciales de máxima relevancia estética.

En la literatura médica, la sensibilidad de la biopsia de ganglio centinela en melanoma de cabeza y cuello oscila entre 88 y $100 \% .10,11,14,34,37,38$ En nuestro estudio la sensibilidad de la técnica se cifra en un $91,6 \%$. En los artículos revisados, el porcentaje de falsos negativos oscila entre 0 y $25 \%$, con una media de $8,69 \%$. Chao y cols., ${ }^{12}$ encuentran más falsos negativos en cabeza y cuello que en otras localizaciones de melanoma. En nuestro estudio no hemos encontrado ningún falso negativo. El caso de ganglio centinela negativo que presentó adenopatía parotídea al cabo de 17 meses no lo consideramos como falso negativo, teniendo en cuenta el largo tiempo transcurrido hasta la aparición de adenopatías y la ausencia de masas sospechosas durante ese tiempo en estudios complementarios realizados. De todas formas, nuestro estudio presenta la limitación de que no podemos analizar adecuadamente los falsos negativos dado que no se realizó linfadenectomía total simultáneamente a la biopsia de ganglio centinela.

En nuestro estudio hemos encontrado un $16,66 \%$ de pacientes con ganglio centinela afectos. En las series revisadas el porcentaje de pacientes afectos oscila entre un 9,4 a un 30\%. En nuestra opinión son cifras significativas de metástasis ocultas en melanoma N0 y que justifican plenamente la técnica de la biopsia de ganglio centinela.

\section{Conclusiones}

El mapeo de los ganglios linfáticos y biopsia de ganglio centinela es una técnica fiable para el diagnóstico de la diseminación linfática del melanoma de cabeza y cuello, en casos adecuadamente operative reading by the gamma probe. ${ }^{14}$ Some authors advocate the use of sulfur colloid at a lower activity level for the head and neck. ${ }^{35}$ In addition the tracer tends to travel very quickly, and in 10 minutes images of ganglionic activity can be obtained, without the need for dynamic lymphoscintigraphy. However, if more than one node is visible, distinguishing these from sentinel nodes or non-sentinel nodes is difficult. According to some authors, this problem could be solved by using isotopic tracers with larger sized particles that would accumulate chiefly in the first nodal echelon, as they would have less capacity for traveling to more distal ganglionic echelons. ${ }^{14}$

The number of nodes that we found per patient in our study was 1.75 nodes. In the series revised the range is between 1.25 and 2.8 nodes per patient. ${ }^{10-12}$

Another controversy surrounding the sentinel node biopsy in melanoma of the head and neck concerns the associated morbidity. A high number of these nodes are small and they are found in areas that are not easily reached, such as in the parotid gland parenchyma, with the resulting risk of lesions being produced in important structures. In our study we have not found any sequelae of this type. Neither did we find in the different works published in the medical literature any significant residual morbidity. 10-13, 27

In the literature there are references to the absorption of Tc-99m sulfur colloid by glandular tissue. ${ }^{35}$ This increases the radiation level in the lymphatic network leading to intraoperative difficulties with recording activity levels in the areas close to glandular structures, a situation that frequently arises with facial melanoma. In our study, in the case in which a sentinel node was not identified, there was a high activity level in the area of the parotid tail. The tissue with high radioactivity was resected, even though in the subsequent histologic study no nodal tissue was observed.

The use of certain types of blue dye has also resulted in controversy. Some authors ${ }^{12,36}$ defend the use of blue methylene claiming an improvement in intraoperative nodal localization, although they also report that blue dye is less visible in the head and neck than in other areas of the anatomy. In our experience we have found permanent sequelae from blue dye when used in sentinel node biopsies of intraoral epidermoid carcinoma cases. This has led us to systematically avoid its use intraoperatively, especially in melanoma cases when the dye is injected into facial areas that are aesthetically very important.

In the medical literature, the sensitivity of the sentinel node biopsy for melanoma of the head and neck varies between 88 and $100 \% .10,11,14,34,37,38$ In our study the sensitivity of the technique was around $91.6 \%$. In the articles revised, the percentage of false negatives varied between 0 and $25 \%$, with a mean of $8.69 \%$. Chao et al ${ }^{12}$ found more false negatives in the head and neck than in other areas with melanoma. In our study we did not encounter any false negatives. The case of the negative sentinel node with parotid swelling after 17 months was not considered a false nega- 
seleccionados. Además de la escasa morbilidad que produce, proporciona información de gran importancia para conocer el pronóstico individual de la enfermedad. A pesar de las prometedoras perspectivas que se vislumbran con esta técnica, consideramos que son necesarios seguimientos a más largo plazo y estudios con series más amplias para obtener conclusiones definitivas.

\section{Bibliografía}

1. Jemal A, Thomas A, Murray T, Thun M. Cancer statistics, 2002. CA Cancer J Clin 2002;52:23-47.

2. Goldsmith HS. Melanoma: an overview. Cancer 1979;29:194-7.

3. Younes MN, Myers JN. Melanoma of the head and neck: current concepts in staging, diagnosis and management. Surg Oncol Clin Nort Am 2004;13:201-29.

4. Medina JE, Canfield V. Malignant melanoma of the head and neck. En: Myers EN, Suen JY, editors. Cancer of the Head and Neck. 3rd ed. Pág.160-83. WB Saunders. Philadelphia, 1996.

5. Ames FC, Sugarbaker EJ, Ballantyne AJ. Analysis of survival and disease control in stage I melanoma of the head and neck. Am / Surg 1976;132:484-9.

6. Morton DL, Wen DR, Wong JH, Economou JS, Cagle LA, Storm FK, Foshag LI, Cochran AJ. Technical details of intraoperative lymphatic mapping for earlystage melanoma. Arch Surg 1992;127:392-9.

7. Wong JH, Cagle LA, Morton DL. Lymphatic drainage of skin to a sentinel lymph node in a feline model. Ann Surg 1991;214:637-41.

8. Lang PG. Current concepts in the management of patients with melanoma. Am J Clin Dermatol 2002;3:401-26.

9. Medina JE, Ferlito A, Brandwein MS, Fisher SR, Pellitteri PK, Shaha AR, Pitman KT, Robbins KT, Rinaldo A, Silver CE, Byers RM, O'Brien C). Current management of cutaneous malignant melanoma of the head and neck. Acta Otolaryngol 2002;122:900-6.

10. Wells KE, Rapaport DP, Cruse CW, Payne W, Albertini J, Berman C, Lyman GH. Sentinel lymph node biopsy in melanoma of the head and neck. Plast Reconstr Surg 1997;100:591-4.

11. Schmalbach CE, Nussenbaum B, Rees RS, Schwartz J, Johnson TM, Bradford CR. Reliability of sentinel lymph node mapping with biopsy for head and neck cutaneous melanoma. Arch Otolaryngol Head Neck Surg 2003;129:61-5.

12. Chao C, Wong SL, Edwards MJ, Ross MI, Reintgen DS, Noyes RD, Stadelmann WK, Lentsch E, McMasters KM. Sentinel lymph node biopsy for head and neck melanomas. Ann Surg Oncol 2003;10:21-6.

13. Ollila DW, Foshag L), Essner R, Stern SL, Morton DL. Parotid region lymphatic mapping and sentinel lymphadenectomy for cutaneous melanoma. Ann Surg Oncol 1999;6:150-4.

14. Jansen L, Koops HS, Nieweg OE, Doping MHE, Kapteijn AE, Balm AJM, Vermey A, Plukker JT, Hoefnagel CA, Piers DA, Kroon BBR. Sentinel node biopsy for melanoma in the head and neck region. Head Neck 2000;22:27-30.

15. Pitman KT, Johnson JT, Brown ML, Myers EN. Sentinel lymph node biopsy in head and neck squamous cell carcinoma. Laryngoscope 2002;112:2101-13.

16. Shoaib T, Soutar DS, MacDonald DG, Camilleri IG, Dunaway DJ, Gray HW, McCurrach GM, Bessent RG, MacLeod TI, Robertson AG. The accuracy of head and neck carcinoma sentinel lymph node biopsy in the clinically NO neck. Cancer 2001;91:2077-83.

17. Pan D, Narayan D, Ariyan S. Merkel cell carcinoma: Five case reports using sentinel lymph node biopsy and a review of 110 new cases. Plast Reconstr Surg 2002;110:1259-65. tive given the long period of time that had elapsed before the appearance of swelling. In the complementary studies carried out during this time no suspicious masses had been observed. In any event, there are limitations in our study as we were unable to analyze the false negatives properly given that complete lymphadenectomies were not carried out at the same time as the sentinel node biopsy.

In our study sentinel node involvement was found in $16.66 \%$ of patients. In the series revised, the percentage of patients with nodal involvement varied between $9.4 \%$ and $30 \%$. In our opinion these are significant figures of occult metastases in NO melanomas to warrant the sentinel node biopsy technique.

\section{Conclusions}

Lymphatic mapping with sentinel node biopsy is a reliable technique for the diagnosis of lymphatic dissemination of head and neck melanoma, for cases that have been properly selected. In addition to the minimal morbidity caused, information is provided that is of great importance when individually assessing the prognosis of the disease. In spite of the promising prospects that we can expect with this technique, we consider that longer follow-ups are necessary together with studies of larger series in order to obtain definitive conclusions. 
18. Ross GL. Shoaib T, Soutar DS, MacDonald DG, Camilleri IG, Bessent RG, Gray HW. The First International Conference on Sentinel Node Biopsy in Mucosal Head and Neck Cancer and adoption of a multicenter trial protocol. Ann Surg Oncol 2002;9:406-10.

19. Balch CM. The role of elective lymph node dissection in melanoma: rationale, results and controversies. / Clin Oncol 1988;1:163-72.

20. Jonk A, Strobbe LJA, Kroon BBR, Mooi WJ, Hart AA, Nieweg OE, Balm AJ. Cervical lymph node metastasis from cutaneous melanoma of the head and neck: a search for prognostic factors. Eur / Surg Oncol 1998;24:298-302.

21. Morton DL, Wen DR, Foshag L), Essner R, Cochran AJ. Intraoperative lymphatic mapping and selective cervical lymphadenectomy for earlystage melanomas of the head and neck. / Clin Oncol 1993;11:17516.

22. Nowecki ZI, Rutkowski P, Nasierowska-Guttmejer A, Ruka W. Sentinel lymph node biopsy in melanoma patients with clinically negative regional lymph nodes- one institution's experience. Melanoma Res 2003;13:35-43.

23. Gershenwald JE, Thompson W, Mansfield PF, Lee JE, Colome MI, Tseng $\mathrm{CH}$, Lee JJ, Balch CM, Reintgen DS, Ross MI. Multi-institutional melanoma lymphatic mapping experience: The prognostic value of sentinel node status in 612 stage I or II melanoma patients. / Clin Oncol 1999;17:976-83.

24. American Joint Committee on Cancer. Malignant melanoma of the skin. En: Greene FL, Page DL, Fleming ID, y cols.,, editors. AJCC staging Manual. Pag 209-20. Lippincott-Raven. Philadelphia, 2002.

25. Rousseau DL Jr, Ross MI, Johnson MM, Prieto VG, Lee JE, Mansfield PF, Gershenwald JE. Revised American Joint Committee on Cancer staging criteria accurately predict sentinel lymph node positivity in clinically node-negative melanoma patients. Ann Surg Oncol 2003;10:56974.

26. Civantos F), Gómez C, Duque C, Pedroso F, Goodwin W], Weed DT, Arnold D, Moffat F. Sentinel node biopsy in oral cavity cancer: correlation with PET scan and immunohistochemistry. Head Neck 2003;25:19.

27. Wagner JD, Park HM, Coleman JJ, Love C, Hayes JT. Cervical sentinel lymph node biopsy for melanomas of the head and neck and upper thorax. Arch Otolaryngol Head Neck Surg 2000;126:313-21.
28. Pu LL, Wells KE, Cruse CW, Shons AR, Reintgen DS. Prevalence of additional positive lymph nodes in complete lymphadenectomy specimens after positive sentinel lymphadenectomy findings for early-stage melanoma of the head and neck. Plast Reconstr Surg 2003;112:43-9.

29. Pathak I, O'Brien CJ, Petersen-Schaeffer K, McNeil EB, McMahon J, Quinn MJ, Thompson JF, McCarthy WM. Do nodal metastases from cutaneous melanoma of the head and neck follow a clinically predictable pattern? Head Neck 2001;23:785-90.

30. Pacella SJ, Lowe L, Bradford C, Marcus BC, Johnson T, Rees R. The utility of sentinel lymph node biopsy in head and neck melanoma in the pediatric population. Plast Reconstr Surg 2003;112:1257-65.

31. Morton DL, Thompson JF, Essner R, Elashoff R, Stern SL, Nieweg OE, Roses DF, Karakousis CP, Mozzillo N, Reintgen D. Validation of the accuracy of intraoperative lymphatic mapping and sentinel-lymphadenectomy for early-stage melanoma: A multicenter trial. Ann Surg 1999;230:453-65.

32. Heaton KM, Sussman JJ, Gershenwald JE, Lee JE, Reintgen DS, Mansfield PF, Ross MI. Surgical margins and prognostic factors in patients with thick (>4mm)primary melanoma. Ann Surg Oncol 1998;5:322-8.

33. Shah JP, Kraus DH, Dubner S, Sarkar S. Patterns of regional lymph node metastases from cutaneous melanoma of the head and neck. Am J Surg 1991;162:320-3.

34. O'Brien CJ, Uren RF, Thompson JF, Howman-Giles RB, Petersen-Schaefer K, Shaw HM, Quinn MJ, McCarthy WH. Prediction of potential metastatic sites in cutaneous head and neck melanoma using lymphoscintigraphy. Am / Surg 1995; 170:461-6.

35. Rasgon BB. Use of low-dose Technetium Tc99m sulphur colloid to locate sentinel lymph nodes in melanoma of the head and neck. Laryngoscope 2001;111: 1366-72.

36. Alex JC, Weaver DL, Fairbank JT, Rankin BS, Krag DN. Gamma-probe guide lymph node localization in malignant melanoma. Surg Oncol 1993;2:303-8.

37. Guelfucci B, Cammilleri S, Gras R, Giovanni A, Chrestian M, Mundler $\mathrm{O}$, Zanaret M. Preliminary analysis of sentinel node detection during surgical treatment of head and neck melanoma. Ann Otolaryngol Chir Cervicofac 2003;120:343-8.

38. Lentsch E), McMasters KM. Sentinel lymph node biopsy for melanoma of the head and neck. Expert Rev Anticancer Ther 2003;3:673-83. 